\title{
Third-Party Conflict Management and the Willingness to Make Concessions
}

\author{
Kyle Beardsley \& Nigel Lo \\ Emory University
}

Author's Note: The authors thank Stephen Gent, Megan Shannon and the anonymous reviewers for their helpful comments. Replication data is available at http://jcr.sagepub.com/. 


\begin{abstract}
Third-party conflict management, particularly legal dispute resolution (arbitration and adjudication) and mediation, can help improve the willingness of disputants to make asymmetric concessions by ameliorating commitment problems and providing political cover. In both regards, and especially pertaining to commitment problems, mediation has substantial limitations when compared to legal dispute resolution. We develop these arguments and test the observable implications on the Issue Correlates of War data. To get traction on the mechanisms at work, we distinguish between challenger concessions and defender concessions, positing that challenger concessions face the primary hurdle of political cover while defender concessions face the primary hurdle of commitment problems. We find that legal dispute resolution strongly increases the propensity for concessions by both challengers and targets, even major asymmetric concessions. Mediation, on the other hand, only helps increase minor challenger concessions. Also consistent with expectations, mediation best enables asymmetric challenger concessions in the highly salient cases that need the most political cover, and legal dispute resolution best enables asymmetric concessions when there has been a history of failed conflict management attempts that perpetuate mistrust.
\end{abstract}




\section{Introduction}

All disputes that end short of complete destruction of one side must involve some form of concession making. The process of "getting to yes" is inherently a process of getting the sides to recognize that concessions are needed to resolve the conflict. Third parties are often quite active in helping to manage international conflicts, but it is not clear how effective they are in promoting concessions nor why they are effective. Existing scholarship has considered how third parties might increase the propensity for formal agreements, contribute to deescalation, or stabilize peace after conflict. ${ }^{1}$ While each of these outcomes relate in various ways to underlying concession making, the connections between third-party involvement and the willingness of each side to accept less than their stated positions remain indirect. The existing scholarship is silent on whether third parties can help both challengers and defenders make concessions, whether third parties can enable asymmetric concessions in particular, and whether third parties can encourage both major concessions and minor concessions.

In this paper, we explore the relationship between third-party conflict management and the ability for disputants to make asymmetric concessions. We argue that when asymmetric concessions are needed to resolve a dispute this creates, inter alia, stark commitment problems for the defending

\footnotetext{
${ }^{1}$ For studies of the impact on formal agreements, see Beardsley (2008), Beardsley, Quinn, Biswas and Wilkenfeld (2006), Bercovitch and Gartner (2006), Dixon (1996), Gent and Shannon (2010), Greig (2001), Rauchhaus (2006), Svensson (2007a,b), Savun (2008), Quinn, Wilkenfeld, Smarick and Asal (2006), Wilkenfeld, Young, Asal and Quinn (2003), and Wilkenfeld, Young, Quinn and Asal (2005). For studies on deescalation, see Dixon (1996), Rauchhaus (2006), Regan and Aydin (2006), and Regan and Stam (2000). For studies of post-conflict peace, see Beardsley (2008, 2011), Beardsley et al. (2006), Gartner and Bercovitch (2006), Greig (2001), Gurses, Rost and McLeod (2008), Mitchell and Hensel (2007), Quinn et al. (2006), Werner (1999), Werner and Yuen (2005), and Wilkenfeld et al. $(2005,2003)$.
} 
side and stark audience constraints for the challenging side. That is, once the disputants recognize what types of bargains are mutually preferable to fighting, they still face substantial difficulties in reaching an agreement when the acceptable alternatives require asymmetric concessions. We further posit that third parties can be particularly useful in such situations to ameliorate commitment problems or provide political cover. If third-party efforts can successfully address these problems, then we should expect them to have a notable effect on the ability for disputants to reach agreements with asymmetric concessions. Successful attempts to reduce commitment problems will especially free up defenders to make asymmetric concessions and successful attempts to reduce political constraints will especially free up challengers to make asymmetric concessions.

To hone in on the mechanisms at work, we thus distinguish between concessions made by those who initiated the challenge and concessions made by those who are defending the status quo. We disaggregate third-party conflict management into mediation-mutually consensual and non-binding third-party involvement - and legal dispute resolution — also mutually consensual but binding third-party involvement, which includes arbitration and adjudication. Despite being a form of conflict management, mediation has substantial limitations when compared to legal dispute resolution. In fact, with regard to commitment problems, mediators typically have neither the ability nor willingness to credibly commit to enforcement, and their non-binding capacity denies them other mechanisms to foster compliance available to arbitrators and courts. With regard to political cover, mediation can be helpful in signaling the prudence of agreements to domestic audiences, but mediators will not be able to shift the culpability for unpopular concessions to the same extent as binding third-party conflict management. We develop these arguments and test the observable implications using the Issue Correlates of War (ICOW) data. 


\section{Barriers to Asymmetric Concessions}

Before we can understand why actors can be reluctant to make the concessions necessary to reach a settlement, we need to define what concessions are. Concessions should be considered relative to the status quo and the challenger's demands. At the beginning of a dispute a status quo that a state wishes to challenge and alter exists. Any movement from the status quo in favor of the challenger is a concession by the defender. Any settlement short of the challenger's demands is a concession by the challenger. Many conflicts do not end with one side completely giving in to the other's demands. It is possible for a dispute to end in relatively symmetric concessions where the ultimate outcome is somewhere in the middle between the status quo and the challenger's demands. In other cases, the concessions are asymmetric, where the ultimate outcome is closer to but not necessarily entirely at either pole. In order to reach an end to a dispute, one side often has to concede much more than the other, like when a challenger backs down relatively empty handed or when a defender acquiesces to most of the challenger's demands.

A disputant especially needs to make asymmetric concessions when the set of mutually acceptable alternatives to fighting is in reality close to its opponent's initial position, with symmetric concessions inferior to the opponent's reservation value. The more asymmetric the concessions needed, the steeper the bargaining constraints disputants face and thus a greater need for thirdparty assistance. That is, after uncertainty and misperception are sufficiently reduced enough for the disputants to converge on what a mutually agreeable settlement should entail—-through fighting or peaceful conflict management with or without assistance - rational disputants face two barriers to reaching asymmetric concessions: commitment problems and domestic political constraints. With regard to the former, peace is blocked by commitment problems when the disputants cannot trust their opponents to abide by an agreement (Fearon 1995, Kydd 2005, Powell 1999, 2004, 2006). 
A disputant will question the credibility of an opponent's pledge to implement an agreement when relative capabilities are shifting in the opponent's favor or when cheating is difficult to detect and police. With regard to the latter, domestic political constraints can block settlement when leaders cannot make the necessary concessions because they would be punished at home for such unpopular decisions, especially when the leaders had previously promised not to back down (Chiozza and Goemans 2004, Colaresi 2004, Debs and Goemans 2010, Fearon 1994, Goemans 2000, Goemans and Fey 2009, Tarar 2006, Tarar and Leventoglu 2009, Trager and Vavreck 2011). Huth and Allee (2002) similarly present a Political Accountability Model that helps explain how domestic institutions shape audience costs for foreign policy decisions and thus affect the onset of conflict and the willingness for the parties to make concessions. Not only must leaders bargain with other states at the international level, they must also bargain with their constituents at the domestic level (Putnam 1988). If domestic actors are unsure about the prudence of any settlements, they may find the concessions that their leaders prefer to make to be unsatisfactory and thus hamper negotiations through the threat of political sanction or holding up the ratification process. ${ }^{2}$

Although we focus on these issues of audience constraints and commitment problems, it is important to note that other problems might also impede the ability for actors to reach a settlement. We focus on these two issues because they are particularly problematic when a mutually acceptable bargain necessitates asymmetric concessions by one of the disputants. In particular, the problem of incomplete information, which is not a topic of focus in this article, is likely to be equally troublesome when the set of possible settlements includes either symmetric or asymmetric concessions. That is, uncertainty over relative capabilities and resolve could lead to bargaining failure when the concessions needed are symmetric - as when both sides have equal bargaining positions but one side

\footnotetext{
${ }^{2}$ See Hensel, Allison and Tures (2009) for a related account of leader constraints in implementing agreements.
} 
is overoptimistic and demands untenable asymmetric concessions - or when they are asymmetric - as when a side in a weaker bargaining position is overoptimistic and demands a more equitable distribution of concessions or even when a side with a better bargaining position demands much more than the other side is willing to yield (Powell 1999). The problem of uncertainty thus does not help us discriminate whether symmetric or asymmetric concessions are more difficult to make in particular cases. So, although existing studies have uncovered how third-party conflict managers might address the problem of incomplete information in conflict bargaining (Favretto 2009, Fey and Ramsay 2010, Kydd 2003, 2006, Rauchhaus 2006, Savun 2008), there is no strong reason to think that reducing uncertainty will have a different effect on the ability to reach asymmetric concessions than the ability to reach symmetric concessions.

\section{Commitment Problems}

Commitment problems and related vulnerability fears are of heightened concern when asymmetric concessions to the challenger are needed for three reasons. First, and most directly, the challenger could be acquiring resources that will further increase its war-fighting capability and thus its capacity to extract even more concessions in the future. Fearon (1995) and Powell (2006) identify such a situation in which actors are bargaining over a good that can increase future power as a special type of a commitment problem. In contrast, asymmetric concessions to the defender involve a challenger backing down, so the defender will not usually gain resources since the status quo prevails. Second, making concessions can also embolden an advancing adversary, as it revises its expectations of what it can ultimately acquire upward and finds it difficult to credibly promise 
to not ask for more in the future (Reiter 2009). ${ }^{3}$ A related argument is that disputants are often wary about developing a reputation for weakness (Alt, Calvert and Humes 1988, Gelpi and Grieco 2001, Walter 2006), and defenders are particularly worried about such a reputation because it would encourage future challenges by both the current adversary and other potential challengers. Third, the underlying factors that led the challenger to become dissatisfied with the status quo and ultimately successful in meriting asymmetric concessions in the first place could lead to even greater demands in the future, especially when tying in with the first point that the gains could be used to even further accelerate the change in relative capabilities and resolve. For example, if one side is experiencing a high rate of growth in power, then the asymmetric concessions that it achieves in the present could be the first of many if the growth continues (Powell 1999, 2004). ${ }^{4}$

According to the above logic, commitment problems are much more of an issue when the set of mutually acceptable bargains consists of outcomes in which asymmetric concessions are made to the challenger. Even though a defender might recognize that it has to concede a disproportionate share, it will often resist doing so in order to avoid giving up even more in the future or to otherwise become

\footnotetext{
${ }^{3}$ While it is true that defenders who receive asymmetric concessions could also be emboldened to challenge the status quo themselves, successful defense does not obviously translate into successful offense because the technologies of war that are useful for the former are not necessarily useful for the latter. Moreover, it should be rare for challengers to start a conflict in which they fare so poorly that the defender becomes emboldened to overturn the status quo in the other direction because this would require a rather extreme degree of overoptimism on the part of the challenger coupled with prior pessimism on the part of the defender.

${ }^{4}$ This logic can apply to asymmetric concessions to a defender only under the very specific circumstance of the contest being a preventive war in which the challenger is attempting to fight a rising defender before the defender becomes dissatisfied with the status quo and becomes a challenger in its own right. While this is possible, this will be a very infrequent occurrence in the universe of disputes considered here that for the most part are not the type of violent exchanges that such a preventive war requires.
} 
vulnerable to ongoing coercion. Efforts, such as third-party conflict management, to ameliorate the commitment problems that put defenders ill at ease should thereby have a more pronounced effect on the ability of the challenger to achieve asymmetric concessions.

\section{Political Constraints}

In contrast, domestic political constraints are stronger in the granting of asymmetric concessions to the defender because challengers will have a tougher time convincing skeptical domestic audiences that they are competent foreign policy makers when they back down from a dispute they initiated. Challengers are the actors that most clearly have chosen to enter into a dispute and they must justify that choice to their publics, which can make backing down costly. The act of initiating a dispute signals to domestic audiences that the leader is optimistic about the chances of revising the status quo, but then subsequently backing down without much to show for it could indicate incompetence and go against the audiences' own perception of what an acceptable agreement looks like - informed by the leader's initial justifications. Defenders, on the other hand, do not choose which disputes are brought against them and will consequently have fewer political constraints in making asymmetric concessions. ${ }^{5}$ Audience costs for asymmetric concessions should thus typically be higher for challengers. While defenders can face audience costs as well for making asymmetric concessions and thereby yielding part of the status quo, it is easier for their domestic audiences to understand that the concessions are motivated out of prudence rather than incompetence. This logic is consistent with Bueno De Mesquita, Siverson and Woller (1992), who find that challenging leaders who lose are at greatest risk of being removed from office. Huth and Allee (2002) also find

\footnotetext{
${ }^{5}$ This is not to say that defenders are not an important part of whether disputes escalate to armed conflict but rather that they are less responsible for the initial challenge of the status quo.
} 
that challenger states are much less likely to concede when elections are approaching and when they lack strong party support in their home legislatures. It is also consistent with the argument that democratic leaders will be especially more selective in choosing when to initiate a conflict because they are more easily sanctioned at home if they challenge and lose (Bueno de Mesquita and Siverson 1995, Gelpi and Griesdorf 2001, Reiter and Stam 1998). ${ }^{6}$

If backing down or giving ground are likely to be immensely unpopular at home for a challenger, especially after a leader had publicly pronounced that there would be no concessions (Fearon 1994, Trager and Vavreck 2011), political cover will be most needed when the set of mutually acceptable bargains consists of outcomes in which the challenger concedes more than the defender. Efforts that effectively provide political cover are thus expected to increase the potential for asymmetric concessions in favor of the defender to be reached.

\section{The Third-Party's Role: Implementation Assistance and}

\section{Political Cover}

Third-party conflict management varies from mediation to legal dispute resolution, which includes arbitration and adjudication. Scholars often conceive of third-party assistance as a form of information transmission (Fey and Ramsay 2010, Kydd 2003, 2006, Mitchell and Hensel 2007, Rauchhaus 2006, Savun 2008), an exercise in leverage (Bercovitch, Anagnoson and Wille 1991, Werner and

\footnotetext{
${ }^{6}$ In a similar vein, Reiter (1995) argues that leaders will often avoid preemptive wars because of the political burdens of initiating conflict, and Chiozza and Goemans (2003) find that states are less likely to initiate crises when they have a high probability of losing office. Slantchev $(2003,2004)$ and Filson and Werner (2002) also argue that initiators will be the actors most prone to revise their expectations over success downward as war progresses, implying a greater need for political cover.
} 
Yuen 2005, Wilkenfeld et al. 2003), or both (Beardsley 2008, Beardsley et al. 2006, Favretto 2009, Quinn et al. 2006, Smith and Stam 2003, Svensson 2007b, Wilkenfeld et al. 2005). Using leverage and information to promote peace, however, captures only a portion of how intermediaries can influence the bargaining environment. Third parties can also provide implementation assistance and political cover. We take both of these third-party functions in turn because each addresses the two critical barriers that are impediments to asymmetric concessions.

Starting with implementation assistance, a third party that bolsters monitoring and enforcement regimes or that otherwise increases the costs of reneging can ameliorate the commitment problems that defenders face when making stark concessions to rising or untrustworthy challengers. The use of third-party legal dispute resolution has a strong potential to reduce such fears of defenders considering asymmetric concessions by making dispute relapse in the future more difficult (Gent and Shannon 2010, Mitchell and Hensel 2007). Arbitration and adjudication are binding, which means that disputants have agreed ahead of time that this is not the first step of many to address the contentious issue. Our explanation, however, cannot stop there since ex ante commitments can be just as incredible as ex post commitments if not more. The question then is how arbitration and adjudication can reduce commitment problems in an anarchic world. We focus on two explanations that have been offered in the international relations and comparative politics literatures.

First, non-compliance with a decision that came out of arbitration or adjudication might be much more costly than non-compliance with an agreement that resulted from a mediated or bilateral peace process because of the steeper reputational costs (Abbott and Snidal 2000, Gent and Shannon 2010, Mitchell and Hensel 2007, Simmons 2000). The end result of arbitration and adjudication is typically some ruling that clearly delineates the ultimate distribution of the good or issue under dispute. With maximum transparency about what would constitute a violation of the ruling, 
actors that defect in the future will be more easily seen as violators of the terms than when there is a violation of the terms to less transparent mediated or bilateral peace processes. This entails that it is easier for states to acquire a reputation for cheating, which could hamper their ability to enjoy benefits of cooperation with other actors in the future (Mitchell and Hensel 2007). Gent and Shannon (2010) use the example of the dispute between Venezuela and Great Britain over the boundaries of Guiana in the 19th century - in which Britain was awarded over $90 \%$ of the territory after decades of bilateral talks had failed to produce a settlement, and Venezuela accepted it nonetheless - to illustrate the importance of having higher costs for reneging on a binding settlement attempt. ${ }^{7}$

Second, actors at home and abroad will find it easier to coordinate in opposition to challengers who cheat on agreements reached through arbitration or adjudication. That is, having a legitimate and legal resolution to a claim enables for a focal enforcement solution to arise (Fisher 1981, Garrett and Weingast 1993, Weingast 1997). In an anarchic system, enforcement is decentralized. Arbitration or adjudication can increase the strength of an enforcement regime by ensuring that a specific third-party state or international organization has staked its credibility to a legally binding

\footnotetext{
${ }^{7}$ One important caveat here is that such reputation concerns are strongest when there are actual market incentives that will flee from uncooperative actors, as in economic-related agreements (Simmons 2000); it is not clear what the analog market incentives are regarding decisions related to territorial, maritime or riparian claims beyond basic bargaining efficiency losses in future negotiations with increasingly suspicious opponents. Aside from market forces, the reputational costs incurred for reneging on a legally binding resolution could be more normative as the international community and domestic actors sanction those that violate their legal obligations out of principle (Abbott and Snidal 2000). Developing a reputation for cheating could also prove costly in the future because a reputation for truthfulness can enhance deterrence capabilities, although it is not clear how much a reputation for keeping promises translates to a reputation for truthfulness in issuing threats (Sartori 2005).
} 
decision and thus becomes more likely to leverage the disputants into compliance or otherwise manage enforcement as needed in the future (Abbott and Snidal 1998, Fang 2010, Mitchell and Hensel 2007, Simmons 2002). Moreover, violations to a legally binding decision can stimulate other actors to counter an actor who has clearly overstepped its bounds (Carrubba 2005, Garrett and Weingast 1993, Johns 2012, Weingast 1997). In some disputes it is not clear which side is the greatest threat to international stability, but a challenger to a previously arbitrated or adjudicated case can be clearly identified as such. In other words, violations to legitimate rulings can be a strong fire alarm that directs enforcement. Mitchell and Hensel (2007) cite the dispute between Nigeria and Cameroon over the Bakassi Peninsula as an example of how initial reluctance by Nigeria to accept an ICJ ruling led to strong follow through by the UN that eventually produced Nigerian compliance. In addition to sanction from international audiences, violating the outcome of a legitimate legal process can also incur domestic audience costs when publics recognize such violations as irresponsible foreign policy behavior (Fang 2010).

In contrast, mediators will be quite limited in assuaging major commitment problems. Without the benefits, expounded upon above, of being able to issue binding resolutions, mediators would need to credibly commit to remaining engaged for the indefinite future if they were to reduce the concerns by defenders of making asymmetric concessions. Mediators, however, typically do not have much ability to enforce agreements, since many mediators lack sufficient capability to punish an offending party with either sanctions or military force. Moreover, mediating third parties that do have the capability to enforce and monitor will not often be willing to make such commitments, given that it would require an expenditure of resources to keep peace elsewhere when such resources could otherwise be spent addressing more immediate threats. Empirically, Werner and Yuen (2005), Beardsley (2008, 2011) and Kuperman (1996) have found that mediators frequently 
fail to secure long-term peace arrangements because their interests in sustaining a peace that they helped promote tend to wane. This is not to say that mediators cannot turn peace processes over to UN or regional peacekeeping, which they often do, but peacekeeping is not special to mediation and often occurs after bilateral settlements as well. Kydd (2006) provides a separate way that mediators help reduce problems of mistrust, by allowing trustworthy parties to be revealed as such. The ability for such mediators to enable defenders to make asymmetric concessions, however, is likely limited because the problems such defenders face pertain to the making of concessions to actual untrustworthy challengers - those that are already rapidly gaining in power or will gain in power by virtue of the concessions and cannot help but demand more in the future. Kydd's mediators only reveal trustworthiness and do not actually make untrustworthy disputants into trustworthy ones, so this mechanism is also not likely to much improve the willingness for a defender to make asymmetric concessions. So, we do not expect mediation to be much better than other forms of conflict management in reducing commitment problem fears that can hinder asymmetric concessions made by a defending party.

If defending states are especially reluctant to grant asymmetric concessions because they are tied to commitment problems, then successful attempts to ameliorate commitment problems should free up defenders to make the concessions. Attempted solutions to commitment problems should have their greatest effect on the actors that are most vulnerable to defection (Staton and Reenock 2010). This leads to the first hypothesis that connects legal dispute resolution, not mediation, to the proclivity for asymmetric concessions in international disputes.

\section{Defender Concessions Hypothesis: Leaders of defending states are more likely to make asymmetric concessions during binding third-party conflict management.}


The other way third-party conflict management addresses barriers to asymmetric concessions is by providing leaders with domestic political cover, which enables them to save face while backing down or making concessions in the presence of domestic opposition. This is also especially true in the case of binding third-party conflict management. Allee and Huth $(2006,219)$ argue that "leaders will seek legal dispute settlement in situations where they anticipate sizable domestic political costs should they attempt to settle a dispute through the making of bilateral, negotiated concessions." With binding conflict management, the political cover is provided by the legal mandate of a court ruling or an arbitrator's judgement. Related to the discussion of how arbitration and adjudication help resolve commitment problems, legal principles and more robust enforcement regimes back the summary judgements. Even if the leaders wanted to, reneging on a decision after legal dispute resolution would entail bearing more international costs than reneging on another type of settlement. Leaders are thus able to point to the legality of the ruling as a legitimate and cost-saving reason to follow the judgement, and they can claim to their publics that the blame for any unpopular concessions lies with the arbitrator or court and that the concessions were made not out of weaknesses but out of a spirit of multilateral cooperation that might be reciprocated in the future (Allee and Huth 2006, Gent and Shannon 2010, Mitchell and Hensel 2007, Simmons 2002).

In support of the notion that binding third-party conflict management is well suited for political cover, Allee and Huth (2006) find that leaders choose legal dispute resolution when they face strong domestic political opposition, when they are more accountable via democratic processes, and when the issue is salient. Simmons (2002) similarly reports that governments are more likely to turn to international legal processes when they lack domestic political capacity to make tough concessions. Simmons (1999, 22-23) describes how the arbitration of the stalemated Ecuador-Peru 
border dispute in 1998 was a key ingredient in getting skeptical domestic audiences on board: "In the case of an ongoing stalemate, one of the advantages of arbitration is to strengthen each government's ability to accept a decision that may be in the public interest, but which is very difficult to propose or accede to in a diplomatic context because of powerful political opposition."

Even though it is not legal dispute resolution, mediation can also help disputants save face, just to a lesser degree. Due to mediation's non-binding nature, it is more difficult for a leader to shift the blame onto the mediator or appeal to a more legitimate process. Leaders can seldom hide behind arguments of there being a settlement process beyond their control during mediation. Mediators with substantial leverage over the belligerents, however, still have some potential to take the blame. For example, political cover provided by heavy-handed mediation has proved important during various stages of the Arab-Israeli conflict, as Stein and Lewis $(1991,13)$ note that "Israeli cabinet members ... have often relied on U.S. mediators to put forward certain difficult positions so that the blame for accepting an unpopular compromise can be put on American 'pressure,' not on their own government." Moreover, mediators, arbitrators, and adjudicators alike have an additional means of offering political cover: they can provide credible signals to a leader's domestic audience. ${ }^{8}$ Third parties, having an insider's perspective of the negotiation process, can make public announcements that the domestic audience can easily obtain and understand. Third-party conflict managers can thus help signal the prudence of concessions when the public is hesitant to make them. Jimmy Carter's mediation of the North Korean nuclear crisis in 1994, for example, improved the American public's perception of compromise such that it actually hamstrung the

\footnotetext{
${ }^{8}$ See Chapman (2007), Chapman and Reiter (2004), Fang (2008), Grieco, Gelpi, Reifler and Feaver (2011) and Thompson (2006) for related studies on how actions from third-parties, especially biased ones, can serve as informative signals.
} 
Clinton administration from pursuing more aggressive courses of sanctions and military threats (Wit, Poneman and Galucci 2004).

For these reasons, we expect legal dispute resolution to provide better political cover than mediation, but for mediation to still do well in comparison to bilateral conflict management. So, this is not to say that mediation is fundamentally incapable of helping actors save face. Mediation can still prove useful in this regard because of its ability to inform domestic publics about the prudence of concessions and because some powerful mediators may enable the disputants to deflect responsibility. One can envision a spectrum of conflict management techniques, with bilateral negotiations at one end, mediation in the middle and legal dispute resolution at the other end, increasing in the potential provision of political cover.

Third-party conflict management, when effective, will improve the willingness of challenger states, the actor in greatest need of political cover for backing down, to make asymmetric concessions. Observing that external conflict management assistance is associated with a higher proclivity for challenger concessions would directly support the logic that third-party conflict management can help provide political cover.

\section{Challenger Concessions Hypothesis: Leaders of challenging states are more likely to} make asymmetric concessions during third-party conflict management, especially in the form of legal dispute resolution.

The above hypotheses are the general expectations that follow from the logic that conflict management techniques which reduce commitment problems should help defending states make asymmetric concessions when needed and conflict management techniques which provide political cover should help challenging states make asymmetric concessions when needed. While the hypotheses have different expectations for the efficacy of mediation, both expect legal dispute res- 
olution to improve the prospects of challenger and defender asymmetric concessions even though the underlying mechanisms are somewhat distinct. It is thus worth testing more specific observable implications of the theory. We test for two conditioning relationships that are expected from the theoretical framework. First, if the above logic is sound, we should expect that third-party conflict management has a pronounced effect on asymmetric challenger concessions when political cover for unpopular concessions is most needed. That is, the extent to which the domestic audience is likely to impose costs on a conceding leader who initiated a dispute should condition the observed effect of outside involvement. Without the potential for audience costs, political cover is not needed and we should not expect third parties to be able to do much to better help challengers make asymmetric concessions. As a specific testable implication, we expect that salience relates strongly to the potential for audience costs for unpopular concessions and thus should positively condition the effect of third-party conflict management. Huth and Allee (2002), Allee and Huth (2006) and Beardsley (2010) posit that salience increases the potential need for political cover when making concessions. Hensel (2001) also argues that high levels of salience generate more attention at home, and he finds that salience correlates positively with decisions to militarize conflict because of the constraints on reaching a settlement.

Salience Hypothesis: Third-party conflict management will have an even stronger positive effect on asymmetric challenger concessions when the saliency to the challenger is high.

Second, and using a parallel logic, we should expect binding third-party conflict management to have an enhanced effect on defender concessions when commitment problems and mistrust are most likely to be present. For, in the absence of mistrust, defenders will be more likely to be willing to concede without fear that their concessions will be turned into even greater demands, 
or perhaps an existential crisis, in the future. One direct indicator of whether states have dubious beliefs about each other's credibility is whether there have been previous attempts to resolve the dispute that failed (Crescenzi 2007, Crescenzi and Enterline 2002, Diehl and Goertz 2000). As Kydd (2005) argues, disputants often learn from previous interactions as to whether an opponent is trustworthy or not. The presence of previous failed management attempts entails two things. First, the existence of a previous failure increases the likelihood that at least one of the parties blames the other for the failure and questions whether their opponent made a good faith effort. This would be especially true if the previous failure was caused by failed implementation. Second, it means that informational problems are less likely to explain the impasse because there should have been learning that occurred during the previous attempt and in subsequent exchanges of hostilities. So, disputes with previous conflict management failures are more likely to suffer from commitment problems and hence require compliance assurances as a prerequisite for defenders to become vulnerable in their asymmetric concessions.

Previous Failures Hypothesis: Binding third-party conflict management will have an even stronger positive effect on asymmetric defender concessions when there have been previous failed attempts to reach an agreement.

\section{Research Design}

To test the hypotheses, we use the Issue Correlates of War (ICOW) data, version 1.1, created by Paul Hensel and Sara Mitchell (Hensel, Mitchell, Sowers II and Thyne 2008). These data contain dyadic information on territorial claims in the Western Hemisphere and Western Europe from 1816 to 2001; river claims in the Western Hemisphere, Western Europe and Middle East from 1900 to 
2001; and Maritime Claims in the Western Hemisphere and in Western and Eastern Europe from 1900 to 2001. An ICOW claim is any instance in which there is explicit evidence of diplomatic contention between official representatives of two or more states.

We limit the data to the instances in which peaceful conflict management is attempted because these are the only instances in which it is possible for concessions to occur in the ICOW data. The problem, however, of only using the set of cases in which conflict management occurred is that it raises the potential for selection bias. Since conflict management attempts are not randomly assigned and the decision to enter into conflict management is likely contingent on the expectations of both the ends and means of conflict management, it can be difficult to uncover the actual efficacy of an intervention like third-party conflict management. Perhaps even more troublesome is that the assignment of mediation, arbitration and adjudication within the set of conflict management attempts is also not random (Allee and Huth 2006, Beardsley 2010, Crescenzi, Kadera, Mitchell and Thyne 2011, Gartner and Bercovitch 2006, Gent and Shannon 2011, Greig 2005, Huth, Croco and Appel 2011, Mitchell 2002, Shannon 2009, Wiegand and Powell 2011). This could lead to selection effects, or endogeneity bias, in which the observed correlation between third-party involvement and concessions has more to do with underlying differences in the types of cases that received intervention versus those that did not than with actual causality (Gartner and Bercovitch 2006).

Any efforts to account for both selection bias and endogeneity bias directly with the estimation of three simultaneous equations are likely to be strongly model dependent. To test the robustness of our findings from standard models, we thus adopt a matching approach in which we find cases with similar profiles among a range of independent variables but that have different treatment groups. Gilligan and Sergenti (2008) use a similar method to study the effects of peacekeeping. We adopt the Iacus, King and Porro (2012) method of coarsened exact matching, where the matching 
algorithm looks for matches among the observations that are nearly balanced, but not perfectly so when values for variables are near each other but not identical. ${ }^{9}$ Unmatched observations are excluded, and we use weighting so that there can be multiple matches with the same profiles. The treatment variable used in the matching algorithm is the occurrence of either mediation or legal-dispute resolution and we describe below how we defined the cut points in the independent variables for the coarsened matching. Since the matching produces treatment and control groups that are not perfectly balanced, we also include the variables that were used for the matching as independent variables. While matching methods are unable to adjust for unobserved variables that could be contributing to selection effects, it is worth emphasizing that with the potential for downward bias that should result from third-party conflict management going to the cases that need it most (Gartner and Bercovitch 2006, Svensson 2008), any observed positive relationships between outside involvement and asymmetric concessions are all the more meaningful.

From the ICOW conflict management data, we use three different dependent variables. The first two are dummy variables of whether the challenger made asymmetric concessions and whether the defender made asymmetric concessions. Logit models are used in the analysis of the covariates of these outcomes, which are directly implied by the hypotheses. The third dependent variable allows for more gradations in the concessions made; it is a six-point, mutually exclusive and exhaustive measure of the type of concessions reached. In distinguishing between challenger and defender concessions, as well as between minor and major concessions, the outcome categories are major challenger concessions, minor challenger concessions, symmetric concessions, minor defender concessions and major defender concessions, with no agreement as the reference category. Table 1 presents the breakdowns for each of the categories - aggregating the values for the challenger

\footnotetext{
${ }^{9}$ We use the software for Stata as described by Blackwell, Iacus, King and Porro (2009).
} 
and target concessions provides the distributions for the two dichotomous dependent variables mentioned above. We use multinomial logit regression models to analyze the covariates of this multi-chotomous outcome variable. While this variable could be construed as ordinal in some applications - for example, in a study of how well each actor fares in its bargains - the application here does not warrant an ordered treatment. That is, we expect that (binding) third-party conflict management has positive effects on the ability for both challengers and defenders to make asymmetric concessions, but treating the dependent variable as ordinal would assume that a positive effect on challenger concessions implies a negative effect on defender concessions.

[Table 1 about here]

The key explanatory variables come directly from the ICOW data and are indicators of whether legal dispute resolution - arbitration or adjudication - or mediation occurred. ${ }^{10}$ Note that other non-binding forms of third-party involvement such as the mere provision of good offices or inquiries are treated as part of the reference category. The hypotheses also propose that salience and previous negotiation failures are variables that condition the effects of third-party conflict management. To test for such conditional effects, we include these variables as interactions with the above variables in some of the models. They are also included as control variables, and as variables on which we match in the non-interaction models. General salience is captured by ICOW's twelve-point dyadic saliency index in the dispute, and we use the separate six-point challenger and target saliency

\footnotetext{
${ }^{10}$ When the binding third-party conflict management variable is disaggregated into separate dummy variables for arbitration and adjudication, the dummy variables consistently have similar effects as each other and as the aggregate variable.
} 
measures for use in the interactions. ${ }^{11}$ Previous negotiation failure is measured as the number of previous conflict management attempts in the previous five years that failed to resolve the conflict. ${ }^{12}$

The other control variables were chosen from variables that existing studies have proposed to be related to both the adoption of conflict management strategies as well as the ease of resolution. One variable that we include is whether both sides have competitive elections. Domestic political institutions can shape both the demand for outside assistance (Allee and Huth 2006, Beardsley 2010, Dixon 1993, Gent and Shannon 2011, Greig 2005, Greig and Diehl 2006) and the ultimate willingness for actors to make concessions (Dixon 1994, Huth and Allee 2002). We define the presence of competitive elections on both sides from the Polity IV (Marshall and Jaggers 2002) component variables such that this variable is true if there are elections for the executive and political participation includes either factional or partisan competition. ${ }^{13}$ International institutions are also likely to shape both the willingness to partake in third-party conflict management and the propensity to make asymmetric concessions. Specifically, states that have made prior commitments to take their disputes to mediation, arbitration or adjudication should be more predisposed to such types of conflict management and are likely to also be predisposed to a willingness to make concessions - the prior commitment could connote an existing sense of optimism in non-coercive processes and the institutions themselves could help passively ameliorate tensions (Mitchell and

\footnotetext{
${ }^{11}$ The ICOW saliency indices capture the importance of the claimed territory, river or maritime zone to the disputants. To coarsen the dyadic measure in the matching, we choose three cut points, at values of 3,6 and 9 to form four bins.

${ }^{12}$ For the matching, we break this variable into two groups according to whether there have been any previous conflict management failures.

${ }^{13}$ For dichotomous variables like these, no coarsening is defined for the matching, as balancing on such variables is exact.
} 
Hensel 2007). In light of this, we include a control variable for the number of commitments that the states have made to settle their disputes peacefully, from the Mutilateral Treaties of Pacific Settlement (MTOPS) data by way of the ICOW data. ${ }^{14}$

We also control for indicators of how difficult the conflicts are to resolve. One such variable is the existence of militarized interstate disputes (MID) over the issue in the previous ten years and is measured dichotomously. This variable specifically helps distinguish contentious rivalries from disputes between actors without much history of the type of animosity that leads to coercive military threats, as Colaresi (2004) has found that audiences are much more likely to punish leaders who make concessions to rivals. As another indicator of conflict intractability, we use the number of previous third-party conflict management attempts. ${ }^{15}$ On the flip side, we include a measure of the relative ease of resolution: the number of previous conflict management attempts in the previous five years that succeeded in moving toward conflict resolution. ${ }^{16}$

Power asymmetry can also shape the preferences for third-party involvement (Beardsley 2010, Greig 2005, Greig and Diehl 2006) and is something important to account for when considering the possibility of asymmetric concessions. That is, in many of the cases, asymmetric concessions might not occur simply because the set of mutually acceptable agreements consists of mostly symmetric

\footnotetext{
${ }^{14}$ For the coarsening, we split this into two bins of no commitments and some commitments.

${ }^{15}$ For the matching, we break this variable into two groups according to whether there has been any previous attempts or not.

${ }^{16}$ See (Wiegand and Powell 2011) for an account of how states are more likely to return to arbitration and adjudication after previous success. Another variable that would help capture the ease of settlement would be the strength of the legal claim (Huth, Croco and Appel 2011), but an equivalent variable does not exist in the context of the ICOW data. For the coarsening, we break this variable into two groups according to whether there have been any previous conflict management successes.
} 
concessions. Addressing issues related to commitment problems and audience costs in such cases should not be expected to produce asymmetric concessions because they are not needed to resolve the disputes. By controlling for power imbalances, this helps us account for the latent need for asymmetric concessions in the first place. We measure power asymmetry as the natural log of the ratio of the strongest actor's military capability to the opponent's, where military capability comes from the conventional CINC index in the National Military Capabilities data (Singer, Bremer and Stuckey 1972). ${ }^{17}$

We use three additional variables to help address substantial heterogeneity in the data that likely affect dispute and outcome dynamics. First, we account for whether or not the dispute is a territorial dispute as opposed to a maritime or riparian dispute. Second, we account for the duration of the dispute up to the point at which the conflict management attempt began because some disputes last a matter of days while others last decades, and the length of conflict has been shown to correlate with better outcomes for the defending state (Slantchev 2004). ${ }^{18}$ Third, we control for the number of other issues that the actors are currently disputing, since issues are not necessarily considered in isolation and concessions with regard to one issue will likely have implications for the potential for concessions on other issues. We thus include a count of how many other ICOW disputes are ongoing in each year for each dyad. ${ }^{19}$

\footnotetext{
${ }^{17}$ For the coarsened matching, we set the cut-point at the value when the stronger disputant is twice as strong as its opponent.

${ }^{18}$ Also, see Greig (2001) and Regan and Stam (2000) for studies of how timing affects third-party conflict management outcomes. For the coarsened matching, we use cut points at one month, one year and ten years.

${ }^{19}$ For the coarsening, we split this into two bins according to whether there are any other ongoing disputes between the protagonists. We also tried including counts of the number of other actors with which each state has concurrent
} 
Table 2 presents the descriptive statistics for all the independent variables in the models - the percentage of ones is listed for binary variables, and the means and standard deviations are given for the other variables. The bivariate correlations between the independent variables are all small, with the partial exception of that between previous third-party involvements and previous failed attempts (correlation of 0.52 ). The key findings are robust to the exclusion of the previous thirdparty involvement variable. All models generate robust standard errors clustered on each claim dyad to account for the potential for correlated errors across repeated events.

[Table 2 about here]

\section{Results}

Starting with the standard logit models of whether third-party conflict management helps enable asymmetric concessions, Model 1 in Table 3 assesses challenger concessions and Model 2 assesses defender concessions. Models 3 and 4 present the same models, but on a sample that has been matched and weighted using coarsened exact matching. We observe that both binding third-party conflict management and mediation help increase the propensity for challenger concessions, while only binding attempts increase the propensity for target concessions. Also, in both instances, the coefficient for binding conflict management is larger than the coefficient for mediation by a statistically significant margin. These findings corroborate the expectation that legal dispute resolution will tend to do even better than mediation in providing political cover and reducing commitment problems. They also confirm that mediation is useful in encouraging asymmetric

disputes, but these were not statistically significant in any of the models and did not affect the robustness of the findings. 
concessions in its own right, but only by challengers, which we have argued are particularly prone to the risk of political embarrassment if they back down. Target states, which we have argued are often concerned with commitment problems when they make major concessions, do not appear much freer to make such concessions when mediators become involved, as anticipated in the theoretical discussion.

[Table 3 about here]

These key results are robust in both the full sample and the matched sample, where the treatment is the occurrence of either mediation or legal-dispute resolution. ${ }^{20}$ The coarsened-exact matching resulted in 157 of 449 matched strata and hence the exclusion of about a third of the observations. Since there are quite a few strata without matches, the multivariate $L_{1}$ statistic as defined in Iacus, King and Porro (2012) is fairly high at 0.86 . This helps justify the matching exercise, although it is also worth noting that the $L_{1}$ statistic for the individual variables never is greater than 0.093 .

One surprising finding emerges from Model 4, which is that mediation has a statistically significant and negative effect on the occurrence of defender concessions in the matched sample. One possibility is that mediators might tend to favor the status quo, as changes to the status quo could create broader issues of instability or begin to threaten the third-parties' own interests. We get some indication that this might be the case when considering that Crescenzi et al. (2011) have found that third parties are more likely to serve as mediators when they have biases toward the

\footnotetext{
${ }^{20}$ Since the matching was performed on the control variables, it is not generally informative to compare the coefficients on those variables across the matched and unmatched results.
} 
defender. Such third parties that are motivated by their biases could steer the negotiations away from asymmetric target concessions. ${ }^{21}$

Table 4 presents the results from the multinomial logit model. ${ }^{22}$ Note that the reference category of the dependent variable is the absence of any concessions and hence the absence of an agreement. Hausman tests do not reject the assumption of independence of irrelevant alternatives, as the coefficients remain similar when dropping observations with each of the outcomes in turn. The basic findings are that binding forms of third-party conflict management increase the propensity for asymmetric concessions of all types. Mediation only increases the propensity for minor challenger concessions. All other relationships between mediation and the occurrence of asymmetric concessions are statistically insignificant. Moreover, mediation has a negative and statistically signifiant effect on symmetric concessions, and further inspection below also reveals that binding third-party involvement is negatively associated with symmetric concessions.

[Table 4 about here]

\footnotetext{
${ }^{21}$ While this is a plausible explanation for the decrease in the propensity for target concessions during mediation, we doubt that third-party biases for the status quo present a viable alternative explanation for the positive relationship with challenger concessions because challengers would be disinclined to accept mediation by biased actors who would consistently foster unfavorable bargains. Since mediation is permissive and non-binding, it is more likely that the positive relationship between third-party conflict management and challenger concessions is a result of the third parties freeing up the challengers to make such concessions rather than the challengers being forced into them. Moreover, this logic should not apply to the effects of binding third-party conflict management because arbitration and adjudication are much more likely to involve unbiased third parties (Gent and Shannon 2010).

${ }^{22}$ For brevity, we omit the results from a multinomial logit model in tandem with coarsened exact matching, which shows consistent findings.
} 
We use Clarify to generate substantive effects from the multinomial logit model (King, Tomz and Wittenberg 2000). Figure 1 displays the predicted probabilities, along with confidence intervals, of experiencing each type of concession with different forms of third-party involvement. ${ }^{23}$ We see that the probability of minor asymmetric challenger concessions increases from $4 \%$ without mediation or binding third-party conflict management to $11 \%$ with mediation and $21 \%$ with arbitration or adjudication. Mediation does less well to increase the probabilities of other types of concessions, while legal dispute resolution increases the probability of major challenger concessions from $2 \%$ to $17 \%$, of minor defender concessions from $9 \%$ to $20 \%$, and of major defender concessions from $5 \%$ to $18 \%$. Interestingly, both binding third-party conflict management and mediation significantly decrease the propensity for symmetric concessions: from $36 \%$ to $14 \%$ for binding involvement and to $23 \%$ for mediation. ${ }^{24}$ This suggests that the disputants do quite well in reaching agreements between their starting positions - when the concessions are not likely to exacerbate commitment problems or audience costs - without much third-party involvement and that the third parties are primarily useful in promoting concessions that are more asymmetric. ${ }^{25}$

\section{[Figure 1 about here]}

We present two additional models that further explore the underlying mechanisms in play. Model 1 in Table 5 again looks at challenger concessions, with the challenger and defender saliency

\footnotetext{
${ }^{23}$ We display $90 \%$ confidence intervals (95\% intervals on each side of the means) because we test the directional hypotheses with one-tailed tests and $95 \%$ confidence intervals in the tables reported above.

${ }^{24}$ These findings are confirmed when a logit model is used with the dependent variable as a dummy variable for symmetric concessions.

${ }^{25}$ Future research should explore if this indicates that third parties actually push for asymmetric concessions over symmetric concessions.
} 
variables interacted with the conflict management variables. ${ }^{26}$ The results show that mediation and challenger saliency have a multiplicative effect that is statistically significant and positive. Calculating the combined coefficients reveals that the effect of mediation becomes statistically significant at high levels of challenger saliency. So, as expected, we find that mediation matters most in enabling asymmetric concessions to occur when there is sufficient salience for the audience to care about the leader's performance on the issue at stake. Related, it is worth noting that the coefficient on the challenger saliency constitutive term is negative and approaching statistical significance $(p<.053$ in a one-tailed test), which means that saliency tends to reduce the likelihood of challenger concessions in the absence of mediation. With mediation, however, saliency does not appear to impede challenger concessions, as the combined coefficient of the interaction term and the challenger saliency constitutive term is not close to statistically significant and has a positive sign. This provides additional support for the notion that third-party conflict management can help challengers save face by counteracting some of the audience costs generated from making asymmetric concessions after initiating a dispute on a salient issue. ${ }^{27}$ It is interesting that the coefficient on the interaction term between binding conflict management and challenger saliency is not statistically significant, although it is positively signed. This suggests that arbitration and adjudication are making other contributions to asymmetric concessions besides just assuaging concerned domestic audiences.

\section{[Table 5 about here]}

\footnotetext{
${ }^{26}$ The matching models are not used here because we have, in effect, two treatment variables.

${ }^{27}$ In an analogous model with defender concessions as the dependent variable, the coefficient on the interaction between defender saliency and mediation is not statistically significant, which further suggests that mediation is working primarily through altering the incentives of the challenger.
} 
Model 2 of Table 5 looks at defender concessions, with the recent peace-process failures variable interacted with the third-party conflict management variables. The results present even more evidence that binding forms of conflict management help reduce defender fears about commitment problems, and that mediation struggles to do the same. Specifically, we observe that the coefficient on the interactive term between binding conflict management and recent failures is positive and statistically significant, as is the coefficient on the binding constitutive term. This means that arbitration and adjudication do well to improve the potential for asymmetric defender concessions, but, as expected, they have an even stronger effect when there is an environment of mistrust from previous failures to reach an agreement. That is, when commitment problems are quite severe, we see that binding third-party conflict management stands out even more in being able to allow the defending states to reach asymmetric concessions. ${ }^{28}$ The effect of mediation, on the other hand, does not appear to be conditioned by previous failures, which again is consistent with the notion that mediation does not much help the ability for defending states to overcome their commitment fears.

\section{Conclusions}

We see that binding forms of third-party conflict management help produce asymmetric concessions, both minor and major and from both challengers and targets. The ability for arbitration and adjudication to increase the likelihood of defender concessions is enhanced when there is a history of conflict management failures. We also see, as expected, that mediation only facilitates the ability

\footnotetext{
${ }^{28}$ When the dependent variable is challenger concessions, the interaction between binding third-party conflict management and previous failures is not statistically significant-consistent with the expectation that it is the defenders that face the greatest commitment-problem constraints when considering asymmetric concessions.
} 
for challengers to make minor concessions. At the same time, mediation can reduce the negative effect that high saliency can have on the ability for challengers to make asymmetric concessions. Finally, there is some evidence that mediation impedes the ability for defenders to make asymmetric concessions, and both types of third-party conflict management have negative relationships with symmetric concessions.

In light of our earlier theoretical discussions, we make the following inferences. First, legal dispute resolution, namely arbitration and adjudication, do quite well in helping to resolve both commitment and audience-constraint problems. The legal process makes it easier for challenging leaders to back down and face criticism at home, and it also allows for defenders to give ground with greater assurance that more challenges or incursions will not be made in the future. Mediation, in contrast, appears to do well in allowing challenging leaders to save face as they back down to some extent, but mediators also appear to be more limited in that regard. The principal limitation is that mediation is a non-binding process, so domestic constituents will not give much slack to leaders that are over-ambitious in their challenges and then point to the third-party's involvement as a key reason for why they ultimately backed down.

Mediators appear to be even more limited in getting the defending side to make asymmetric concessions. Since mediation is not, by definition, part of a binding process that creates a focal enforcement solution or that otherwise confers legal legitimacy onto a final settlement, the primary mechanism for mediators to address commitment problems is to promise security guarantees and/or peacekeeping. Security guarantees, however, face their own commitment problems, and peacekeepers can also be deployed in settlements that did not involve a third party during the negotiation phase. Moreover, there is some evidence that mediators actually impede asymmetric concessions by target states. One possible explanation is that, more so than arbitrators or adjudi- 
cators who are selected because they are disinterested (Gent and Shannon 2010), mediators will be more likely to have a specific preference for a stalemate outcome in which the status quo prevails. For example, Theodore Roosevelt's preferred outcome when he mediated in the Russo-Japanese War was for Japan, the rising great power, to not achieve too much so that a stalemate between Russia and Japan would persist and the US would have a firmer foothold in Pacific affairs (Princen 1992).

We must keep in mind that the outcomes of interest here are short-term ones, and existing studies have shown that the long-term outcomes of mediation are typically less favorable because reliance on the third party can decrease the ability for peace to become self enforcing (Beardsley 2008, 2011, Werner and Yuen 2005). In fact, the finding that mediators do not at all do well in increasing the incentives for defenders to make concessions comports well with the logic that mediators struggle to credibly commit to sustained post-conflict implementation assistance. Arbitration and adjudication are less apt to produce agreements that later prove fragile. Unlike mediation, the means by which arbitration and adjudication address commitment problems are not heavily based on security guarantees that can often be fleeting but rather on generating a clear focal solution and the strengthening of reputational costs. Agreements that result from binding third-party conflict management are thereby less prone to fall apart when the conflict manager's influence wanes over time.

Does this then mean that arbitration and adjudication should be recommended for all disputes? We must hesitate to universally recommend binding third-party conflict management for three reasons. First, the most rigorous tests here involved matching techniques that only produce average treatment effects which cannot tell us what the effects of third-party conflict management would be in cases in which it does not typically occur. Second, and related to the first, we cannot conclude 
that binding third-party conflict management will have similar effects if randomly assigned to cases that would not otherwise have chosen that path because one of the crucial ways in which arbitration and adjudication work to reduce audience pressures and commitment problems is through mutual recognition of its legitimacy. We should expect arbitration or adjudication to have much less of an impact in cases in which the disputants do not feel obliged to comply with the decision, which is likely to occur when binding conflict management is imposed rather than sought. Third, legal dispute resolution could actually make it more difficult to enter into negotiations in the first place. If arbitration and adjudication do well to make implementation relatively permanent, then the disputants are likely to find the stakes higher and may even try to avoid compromise by pursuing a complete victory. ${ }^{29}$ If disputants would like to keep their options open on the most important cases (Gent and Shannon 2011, Hensel 2001), then this suggests that they will tend to avoid assisted conflict management altogether if they were required to go through arbitration or adjudication.

\section{References}

Abbott, Kenneth W. and Duncan Snidal. 1998. "Why States Act through Formal International Organizations." Journal of Conflict Resolution 42(1):3-32.

Abbott, Kenneth W. and Duncan Snidal. 2000. "Hard and Soft Law in International Governance." International Organization 54(3):421-456.

Allee, Todd L. and Paul K. Huth. 2006. "Legitimizing Dispute Settlement: International Legal Rulings as Domestic Political Cover." American Political Science Review 100(2):219-234.

Alt, James E., Randall L. Calvert and Brian D. Humes. 1988. "Reputation and Hegemonic Stability: A Game-Theoretic Analysis." American Political Science Review 82(2):445-466.

Beardsley, Kyle. 2008. "Agreement without Peace? International Mediation and Time Inconsistency Problems." American Journal of Political Science 52(4):723-740.

Beardsley, Kyle. 2010. "Pain, Pressure, and Political Cover: Explaining Mediation Selection." Journal of Peace Research 47(4):395-406.

\footnotetext{
${ }^{29}$ See Fearon (1998) for an argument that successful implementation is likely to make the negotiation phase more contentious.
} 
Beardsley, Kyle. 2011. The Mediation Dilemma. Ithaca, NY: Cornell University Press.

Beardsley, Kyle, David Quinn, Bidisha Biswas and Jonathan Wilkenfeld. 2006. "Mediation Style and Crisis Outcomes." Journal of Conflict Resolution 50(1):58-86.

Bercovitch, Jacob, J. Theodore Anagnoson and Donnette L. Wille. 1991. "Some Conceptual Issues and Empirical Trends in the Study of Successful Mediation in International Relations." Journal of Peace Research 28(1):7-17.

Bercovitch, Jacob and Scott Sigmund Gartner. 2006. "Is there Method in the Madness of Mediation? Some Lessons for Mediators from Quantitative Studies of Mediation." International Interactions 32:329-354.

Blackwell, Matthew, Stefano Iacus, Gary King and Giuseppe Porro. 2009. "CEM: Coarsened Exact Matching in Stata." Stata Journal 9(4):524-546.

Bueno De Mesquita, Bruce, Randolph M. Siverson and Gary Woller. 1992. "War and the Fate of Regimes: A Comparative Analysis." American Political Science Review 86(3):638-646.

Bueno de Mesquita, Bruce and Randolph Siverson. 1995. "War and the Survival of Political Leaders: A Comparative Study of Regime Types and Accountability." American Political Science Review 89(4):841-855.

Carrubba, Clifford J. 2005. "Courts and Compliance in International Regulatory Regimes." Journal of Politics 67(3):669-689.

Chapman, Terrence L. 2007. "International Security Institutions, Domestic Politics, and Institutional Legitimacy." Journal of Conflict Resolution 51(1):134-166.

Chapman, Terrence L. and Dan Reiter. 2004. "The United Nations Security Council and the Rally 'Round the Flag Effect." Journal of Conflict Resolution 48(6):886-909.

Chiozza, Giacomo and H. E. Goemans. 2003. "Peace through Insecurity: Tenure and International Conflict." Journal of Conflict Resolution 47(4):443-67.

Chiozza, Giacomo and H. E. Goemans. 2004. "International Conflict and the Tenure of Leaders: Is War Still Ex Post Inefficient?" American Journal of Political Science 48(3):604-619.

Colaresi, Michael. 2004. "When Doves Cry: International Rivalry, Unreciprocated Cooperation, and Leadership Turnover." American Journal of Political Science 48(3):555-570.

Crescenzi, Mark J. C. 2007. "Reputation and Interstate Conflict." American Journal of Political Science 51(2):382-396.

Crescenzi, Mark J. C. and Andrew J. Enterline. 2002. "Time Remembered: A Dynamic Model of Interstate Interaction." International Studies Quarterly 45(3):409-431.

Crescenzi, Mark J. C., Kelly M. Kadera, Sara McLaughlin Mitchell and Clayton L. Thyne. 2011. "A Supply Side Theory of Mediation." International Studies Quarterly 55(4):1069-1094. 
Debs, Alexandre and HE Goemans. 2010. "Regime Type, the Fate of Leaders, and War." American Political Science Review 104(3):430-445.

Diehl, Paul and Gary Goertz. 2000. War and Peace in International Rivalry. Ann Arbor: University of Michigan.

Dixon, William J. 1993. "Democracy and the Management of International Conflict." Journal of Conflict Resolution 37(1):42-68.

Dixon, William J. 1994. "Democracy and the Peaceful Settlement of International Conflict." American Political Science Review 88(1):14-32.

Dixon, William J. 1996. "Third-Party Techniques for Preventing Conflict Escalation and Promoting Peaceful Settlement." International Organization 50(4):653-681.

Fang, Songying. 2008. "The Informational Role of International Institutions and Domestic Politics." American Journal of Political Science 52(2):304-321.

Fang, Songying. 2010. "The Strategic Use of International Institutions in Dispute Settlement." Quarterly Journal of Political Science 5:107-131.

Favretto, Katja. 2009. "Should Peacemakers Take Sides? Major Power Mediation, Coercion, and Bias." American Political Science Review 103(02):248-263.

Fearon, James D. 1994. "Domestic Political Audiences and the Escalation of International Disputes." American Political Science Review 88(3):577-592.

Fearon, James D. 1995. "Rationalist Explanations for War." International Organization 49(3):379414.

Fearon, James D. 1998. "Bargaining, Enforcement, and International Cooperation." International Organization 52(2):269-305.

Fey, Mark and Kristopher W. Ramsay. 2010. "When Is Shuttle Diplomacy Worth the Commute? Information Sharing through Mediation." World Politics 62(04):529-560.

Filson, Darren and Suzanne Werner. 2002. "A Bargaining Model of War and Peace: Anticipating the Onset, Duration, and Outcome of War." American Journal of Political Science pp. 819-837.

Fisher, Roger. 1981. Improving Compliance with International Law. Charlottesville, VA: University of Virginia.

Garrett, Geoffrey and Barry R. Weingast. 1993. Ideas, Interests, and Institutions: Constructing the European Community's Internal Market. In Ideas and Foreign Policy: Beliefs, Institutions, and Political Change, ed. Joshua Goldstein and Robert O. Keohane. Ithaca, NY: Cornell University.

Gartner, Scott S. and Jacob Bercovitch. 2006. "Overcoming Obstacles to Peace: The Contribution of Mediation to Short-Lived Conflict Settlements." International Studies Quarterly 50(4):819840. 
Gelpi, Christopher F. and Michael Griesdorf. 2001. "Winners or Losers? Democracies in International Crisis, 1918-94." American Political Science Review 95(3):633-647.

Gelpi, Christopher and Joseph M. Grieco. 2001. "Attracting Trouble: Democracy, Leadership Tenure, and the Targeting of Militarized Challenges, 1918-1992." Journal of Conflict Resolution 45(6):794-817.

Gent, Stephen E. and Megan Shannon. 2010. "The Effectiveness of International Arbitration and Adjudication: Getting into a Bind." Journal of Politics 72(2):366-380.

Gent, Stephen E. and Megan Shannon. 2011. "Decision Control and the Pursuit of Binding Conflict Management: Choosing the Ties that Bind." Journal of Conflict Resolution 55(5):710-734.

Gilligan, Michael J. and Ernest J. Sergenti. 2008. "Do UN Interventions Cause Peace? Using Matching to Improve Causal Inference." Quarterly Journal of Political Science 3(2):89-122.

Goemans, H. E. 2000. War and Punishment: The Causes of War Termination and the First World War. Princeton, NJ: Princeton University Press.

Goemans, H.E. and Mark Fey. 2009. "Risky but Rational: War as an Institutionally Induced Gamble." The Journal of Politics 71(01):35-54.

Greig, J. Michael. 2001. "Moments of Opportunity: Recognizing Conditions of Ripeness for International Mediation Between Enduring Rivals." Journal of Conflict Resolution 45(6):691-718.

Greig, J. Michael. 2005. "Stepping into the Fray: When Do Mediators Mediate?" American Journal of Political Science 49(2):249-266.

Greig, J. Michael and Paul F. Diehl. 2006. "Softening Up: Making Conflicts More Amenable to Diplomacy." International Interactions 32:355-384.

Grieco, Joseph M., Christopher Gelpi, Jason Reifler and Peter D. Feaver. 2011. "Let's Get a Second Opinion: International Institutions and American Public Support for War." International Studies Quarterly 55(2):563-83.

Gurses, Mehmet, Nicolas Rost and Patrick McLeod. 2008. "Mediating Civil War Settlements and the Duration of Peace." International Interactions 34(2):129-155.

Hensel, Paul. 2001. "Contentious Issues and World Politics: The Management of Territorial Claims in the Americas, 1816-1992." International Studies Quarterly 45(1):81-109.

Hensel, Paul, Michael E. Allison and John A. Tures. 2009. "Credible Commitments and Negotiations over Territory." Presented at the Annual Meeting of the American Political Science Association in Toronto.

Hensel, Paul R., Sara McLaughlin Mitchell, Thomas E. Sowers II and Clayton L. Thyne. 2008. "Bones of Contention: Comparing Territorial, Maritime, and River Issues." Journal of Conflict Resolution 52(1):117-143. 
Huth, Paul. K., Sarah E. Croco and Benjamin J. Appel. 2011. "Does International Law Promote the Peaceful Settlement of International Disputes? Evidence from the Study of Territorial Conflicts since 1945." American Political Science Review 105(2):415-436.

Huth, Paul K. and Todd L. Allee. 2002. The Democratic Peace and Territorial Conflict in the Twentieth Century. New York: Cambridge University Press.

Iacus, Stefano M., Gary King and Giuseppe Porro. 2012. "Causal Inference without Balance Checking: Coarsened Exact Matching." Political Analysis 20(1):1-24.

Johns, Leslie. 2012. "Courts as Coordinators: Endogenous Enforcement and Jurisdiction in International Adjudication." Journal of Conflict Resolution 56(2):257-289.

King, Gary, Michael Tomz and Jason Wittenberg. 2000. "Making the Most of Statistical Analyses: Improving Interpretation and Presentation." American Journal of Political Science 44(2):347-61.

Kuperman, Alan J. 1996. "The Other Lesson of Rwanda: Mediators Sometimes Do More Damage than Good." SAIS Review 16(1):221-240.

Kydd, Andrew. 2003. "Which Side Are You on?: Bias, Credibility and Mediation." American Journal of Political Science 47(4):597-611.

Kydd, Andrew H. 2005. Trust and Mistrust in International Relations. Princeton, NJ: Princeton University Press.

Kydd, Andrew H. 2006. "When Can Mediators Build Trust?" American Political Science Review 100(3):449-462.

Marshall, Monty and Keith Jaggers. 2002. Polity IV Project: Dataset User's Manual. http://www.cidcm.umd.edu/inscr/polity: . September 25.

Mitchell, Sara McLaughlin. 2002. "A Kantian System? Democracy and Third-Party Conflict Resolution." American Journal of Political Science 46(4):749-759.

Mitchell, Sara McLaughlin and Paul R. Hensel. 2007. "International Institutions and Compliance with Agreements." American Journal of Political Science 51(4):721-737.

Powell, Robert. 1999. In the Shadow of Power: States and Strategies in International Politics. Princeton, NJ: Princeton University Press.

Powell, Robert. 2004. "The Inefficient Use of Power: Costly Conflict with Complete Information." American Political Science Review 98(2):231-241.

Powell, Robert. 2006. "War as a Commitment Problem." International Organization 60:169-203.

Princen, Thomas. 1992. Intermediaries in International Conflict. Princeton, NJ: Princeton University Press.

Putnam, Robert D. 1988. "Diplomacy and Domestic Politics: The Logic of Two-Level Games." International Organization 42(3):427-460. 
Quinn, David, Jonathan Wilkenfeld, Kathleen Smarick and Victor Asal. 2006. "Power Play: Mediation in Symmetric and Asymmetric International Crises." International Interactions 32(4):441470.

Rauchhaus, Robert. 2006. "Asymmetric Information, Mediation and Conflict Management." World Politics 58(2):207-241.

Regan, Patrick and Aysegul Aydin. 2006. "Diplomacy and other Forms of Intervention in Civil Wars." Journal of Conflict Resolution 50(5):736-756.

Regan, Patrick M. and Allan C. Stam. 2000. "In the Nick of Time: Conflict Management, Mediation Timing, and the Duration of Interstate Disputes." International Studies Quarterly 44:239-260.

Reiter, Dan. 1995. "Exploding the Powder Keg Myth: Preemptive Wars Almost Never Happen." International Security 20(2):5-34.

Reiter, Dan. 2009. How Wars End. Princeton, NJ: Princeton University.

Reiter, Dan and Allan C. Stam. 1998. "Democracy, War Initiation, and Victory." American Political Science Review 92(2):377-389.

Sartori, Anne E. 2005. Deterrence by Diplomacy. Princeton, NJ: Princeton University Press.

Savun, Burcu. 2008. "Information, Bias, and Mediation Success." International Studies Quarterly $52(1): 25-47$.

Shannon, Megan. 2009. "Preventing War and Providing the Peace?" Conflict Management and Peace Science 26(2):144-163.

Simmons, Beth A. 1999. "Territorial disputes and their resolution." United States Institute of Peace (USIP) Press, Washington DC, USA.

Simmons, Beth A. 2000. "International Law and State Behavior: Commitment and Compliance in International Monetary Affairs." American Political Science Review 94(4):819-835.

Simmons, Beth A. 2002. "Capacity, Commitment, and Compliance: International Institutions and Territorial Disputes." Journal of Conflict Resolution 46(6):829-856.

Singer, J. David, Stuart Bremer and John Stuckey. 1972. Capability Distribution, Uncertainty, and Major Power War. In Peace, War, and Numbers, ed. Bruce M. Russett. Beverly Hills, CA: Sage pp. 19-48.

Slantchev, Branislav. 2003. "The Principle of Convergence in Wartime Negotiations." American Political Science Review 97(4):621-632.

Slantchev, Branislav L. 2004. "How Initiators End Their Wars: The Duration of Warfare and the Terms of Peace." American Journal of Political Science 48(4):813-829.

Smith, Alastair and Allan Stam. 2003. "Mediation and Peacekeeping in a Random Walk Model of Civil and Interstate War." International Studies Review 5(4):115-135. 
Staton, Jeffrey K. and Christopher Reenock. 2010. "Substitutable Protections: Credible Commitments Devices and Socioeconomic Insulation." Political Research Quarterly 63(1):115-128.

Stein, Kenneth W. and Samuel W. Lewis. 1991. Making Peace among Arabs and Israelis. Washington, DC: United States Institute of Peace.

Svensson, Isak. 2007a. "Bargaining, Bias and Peace Brokers: How Rebels Commit to Peace." Journal of Peace Research 44(2):177-194.

Svensson, Isak. 2007b. "Mediation with Muscles or Minds? Exploring Power Mediators and Pure Mediators in Civil Wars." International Negotiation 12:229-248.

Svensson, Isak. 2008. "Do Mediators Go Where they Are Needed Most? Mediation Selection in Civil Wars." Unpublished manuscript.

Tarar, Ahmer. 2006. "Diversionary Incentives and the Bargaining Approach to War." International Studies Quarterly 50(1):169-188.

Tarar, Ahmer and Bahar Leventoglu. 2009. "Public Commitment in Crisis Bargaining." International Studies Quarterly 53(3):817-839.

Thompson, Alexander. 2006. "Coercion through IOs: The Security Council and the Logic of Information Transmission." International Organization 60(01):1-34.

Trager, Robert F. and Lynn Vavreck. 2011. "The Political Costs of Crisis Bargaining: Rhetoric and the Role of Party." American Journal of Political Science 55(3):526-545.

Walter, Barbara F. 2006. "Building Reputation: Why Governments Fight Some Separatists but Not Others." American Journal of Political Science 50(2):335-364.

Weingast, Barry R. 1997. "The Political Foundations of Democracy and the Rule of Law." American Political Science Review 91(2):245-263.

Werner, Suzanne. 1999. "The Precarious Nature of Peace: Resolving the Issues, Enforcing the Settlement, and Renegotiating the Terms." American Journal of Political Science 43(3):912934.

Werner, Suzanne and Amy Yuen. 2005. "Making and Keeping Peace." International Organization 59(2):261-292.

Wiegand, Krista E. and Emelia Justyna Powell. 2011. "Past Experience, Quest for the Best Forum, and Peaceful Attempts to Resolve Territorial Disputes." Journal of Conflict Resolution $55(1): 33-59$.

Wilkenfeld, Jonathan, Kathleen J. Young, David M. Quinn and Victor Asal. 2005. Mediating International Crises. New York: Routledge.

Wilkenfeld, Jonathan, Kathleen Young, Victor Asal and David Quinn. 2003. "Mediating International Crises: Cross-National and Experimental Perspectives." Journal of Conflict Resolution 47(3):279-301.

Wit, Joel S., Daniel B. Poneman and Robert L. Galucci. 2004. Going Critical: The First North Korean Nuclear Crisis. Washington, DC: Brookings. 
Table 1: Concession Categories

\begin{tabular}{lcc}
\hline \hline Category & Number & Percentage \\
\hline & & \\
No Concessions & 708 & 44 \\
High Challenger Concessions & 55 & 3 \\
Low Challenger Concessions & 83 & 5 \\
Symmetric Concessions & 574 & 35 \\
Low Defender Concessions & 143 & 9 \\
High Defender Concessions & 63 & 4 \\
\hline \hline
\end{tabular}


Table 2: Descriptive Statistics

\begin{tabular}{lccc}
\hline \hline & & & \\
Variable & Percentage & Mean & SD \\
\hline Binding Third-Party & 4.31 & & \\
Mediation & 7.87 & & \\
Dyadic Salience & & 7.09 & 2.34 \\
Conflict Management Failures, 5 yrs & & 1.12 & 1.69 \\
Competitive Gov., dyad & 19.62 & & \\
ln(Capability Ratio) & & 1.99 & 1.80 \\
Previous MID, 10 yrs & 27.55 & & \\
Territorial Issue & 59.90 & & \\
Previous 3rd Party Attempts & & 1.85 & 3.81 \\
ln(Claim Duration) & & 8.38 & 1.73 \\
Other Claims & & 0.82 & 1.33 \\
Pacific Settlement Commitments & & 2.67 & 2.70 \\
Conflict Management Successes, 5 yrs & & 0.64 & 1.22 \\
\hline \hline
\end{tabular}


Table 3: Logit Model of Concessions, Base Models

\begin{tabular}{|c|c|c|c|c|}
\hline IV & $\begin{array}{c}\text { 1: } \\
\text { Challenger }\end{array}$ & $\begin{array}{c}2: \\
\text { Defender }\end{array}$ & $\begin{array}{c}\text { 3: } \\
\text { Challenger } \\
\text { Matched }\end{array}$ & $\begin{array}{c}4: \\
\text { Defender } \\
\text { Matched }\end{array}$ \\
\hline Binding Third-Party & $\begin{array}{c}2.464^{* *} \\
(0.322)\end{array}$ & $\begin{array}{l}1.275^{* *} \\
(0.281)\end{array}$ & $\begin{array}{c}2.631^{* *} \\
(0.403)\end{array}$ & $\begin{array}{c}1.705^{* *} \\
(0.362)\end{array}$ \\
\hline Mediation & $\begin{array}{l}0.633^{*} \\
(0.336)\end{array}$ & $\begin{array}{l}-0.454 \\
(0.431)\end{array}$ & $\begin{array}{l}0.745^{*} \\
(0.435)\end{array}$ & $\begin{array}{l}-1.936^{*} \\
(1.016)\end{array}$ \\
\hline Dyadic Salience & $\begin{array}{l}-0.0231 \\
(0.0505)\end{array}$ & $\begin{array}{l}0.00836 \\
(0.0425)\end{array}$ & $\begin{array}{l}-0.168^{*} \\
(0.0724)\end{array}$ & $\begin{array}{c}-0.00446 \\
(0.0610)\end{array}$ \\
\hline Conflict Management Failures, 5 yrs & $\begin{array}{l}-0.0138 \\
(0.0666)\end{array}$ & $\begin{array}{l}-0.0765 \\
(0.0719)\end{array}$ & $\begin{array}{c}0.119 \\
(0.0979)\end{array}$ & $\begin{array}{c}-0.0948 \\
(0.109)\end{array}$ \\
\hline Competitive Gov., dyad & $\begin{array}{l}-0.151 \\
(0.304)\end{array}$ & $\begin{array}{c}0.00517 \\
(0.254)\end{array}$ & $\begin{array}{c}0.458 \\
(0.490)\end{array}$ & $\begin{array}{c}0.257 \\
(0.403)\end{array}$ \\
\hline $\ln ($ Capability Ratio $)$ & $\begin{array}{l}-0.0708 \\
(0.0712)\end{array}$ & $\begin{array}{c}0.0268 \\
(0.0503)\end{array}$ & $\begin{array}{c}-0.00752 \\
(0.0823)\end{array}$ & $\begin{array}{l}-0.0741 \\
(0.0654)\end{array}$ \\
\hline Previous MID, 10 yrs & $\begin{array}{l}0.0266 \\
(0.247)\end{array}$ & $\begin{array}{c}-0.00896 \\
(0.245)\end{array}$ & $\begin{array}{c}0.544 \\
(0.367)\end{array}$ & $\begin{array}{l}-0.209 \\
(0.381)\end{array}$ \\
\hline Territorial Issue & $\begin{array}{l}-0.425 \\
(0.303)\end{array}$ & $\begin{array}{c}0.232 \\
(0.221)\end{array}$ & $\begin{array}{l}-0.119 \\
(0.351)\end{array}$ & $\begin{array}{r}-0.0368 \\
(0.335)\end{array}$ \\
\hline Previous 3rd Party Attempts & $\begin{array}{c}-0.103 \\
(0.0686)\end{array}$ & $\begin{array}{c}0.00463 \\
(0.0339)\end{array}$ & $\begin{array}{l}-0.208^{*} \\
(0.0960)\end{array}$ & $\begin{array}{c}-0.00219 \\
(0.0583)\end{array}$ \\
\hline $\ln$ (Claim Duration) & $\begin{array}{c}0.0266 \\
(0.0813)\end{array}$ & $\begin{array}{c}-0.199 * * \\
(0.0484)\end{array}$ & $\begin{array}{c}-0.0851 \\
(0.117)\end{array}$ & $\begin{array}{c}-0.282^{* *} \\
(0.0932)\end{array}$ \\
\hline Other Claims & $\begin{array}{l}0.00819 \\
(0.0827)\end{array}$ & $\begin{array}{c}0.0385 \\
(0.0753)\end{array}$ & $\begin{array}{l}-0.103 \\
(0.133)\end{array}$ & $\begin{array}{c}0.0577 \\
(0.0971)\end{array}$ \\
\hline Pacific Settlement Commitments & $\begin{array}{l}0.00454 \\
(0.0484)\end{array}$ & $\begin{array}{c}0.0297 \\
(0.0502)\end{array}$ & $\begin{array}{c}0.0220 \\
(0.0748)\end{array}$ & $\begin{array}{c}0.0223 \\
(0.0756)\end{array}$ \\
\hline Conflict Management Successes, 5 yrs & $\begin{array}{l}0.0278 \\
(0.111)\end{array}$ & $\begin{array}{c}-0.0988 \\
(0.102)\end{array}$ & $\begin{array}{l}0.0620 \\
(0.198)\end{array}$ & $\begin{array}{l}-0.136 \\
(0.127)\end{array}$ \\
\hline Constant & $\begin{array}{c}-2.189^{* *} \\
(0.692)\end{array}$ & $\begin{array}{l}-0.626 \\
(0.516)\end{array}$ & $\begin{array}{l}-0.862 \\
(1.202)\end{array}$ & $\begin{array}{c}0.420 \\
(0.836)\end{array}$ \\
\hline Observations & 1601 & 1601 & 1036 & 1036 \\
\hline
\end{tabular}

${ }^{* *} p<0.01,{ }^{*} p<0.05$ in a one-tailed test. Standard errors in parentheses. 
Table 4: Multinomial Logit Model of Concessions

\begin{tabular}{|c|c|c|c|c|c|}
\hline IV & $\begin{array}{c}\text { 1: } \\
\text { Challenger } \\
\text { High }\end{array}$ & $\begin{array}{c}\text { 2: } \\
\text { Challenger } \\
\text { Low }\end{array}$ & $\begin{array}{c}\text { 3: } \\
\text { Symmetric }\end{array}$ & $\begin{array}{c}4: \\
\text { Defender } \\
\text { Low }\end{array}$ & $\begin{array}{c}5: \\
\text { Defender } \\
\text { High }\end{array}$ \\
\hline Binding Third-Party & $\begin{array}{c}3.706^{* *} \\
(0.618)\end{array}$ & $\begin{array}{l}3.134^{* *} \\
(0.585)\end{array}$ & $\begin{array}{c}0.609 \\
(0.557)\end{array}$ & $\begin{array}{c}2.430^{* *} \\
(0.583)\end{array}$ & $\begin{array}{c}2.847^{* *} \\
(0.630)\end{array}$ \\
\hline Mediation & $\begin{array}{l}-0.507 \\
(0.721)\end{array}$ & $\begin{array}{l}0.648^{*} \\
(0.375)\end{array}$ & $\begin{array}{l}-0.685^{*} \\
(0.315)\end{array}$ & $\begin{array}{l}-0.517 \\
(0.526)\end{array}$ & $\begin{array}{l}-0.861 \\
(0.774)\end{array}$ \\
\hline Dyadic Salience & $\begin{array}{c}-0.0562 \\
(0.0761)\end{array}$ & $\begin{array}{l}-0.0383 \\
(0.0588)\end{array}$ & $\begin{array}{c}-0.00830 \\
(0.0332)\end{array}$ & $\begin{array}{c}0.0160 \\
(0.0487)\end{array}$ & $\begin{array}{l}-0.0286 \\
(0.0824)\end{array}$ \\
\hline Conflict Management Failures, 5 yrs & $\begin{array}{l}-0.200 \\
(0.136)\end{array}$ & $\begin{array}{l}-0.0472 \\
(0.0857)\end{array}$ & $\begin{array}{c}-0.183^{* *} \\
(0.0480)\end{array}$ & $\begin{array}{c}-0.176^{* *} \\
(0.0737)\end{array}$ & $\begin{array}{l}-0.124 \\
(0.167)\end{array}$ \\
\hline Competitive Gov., dyad & $\begin{array}{l}-0.548 \\
(0.551)\end{array}$ & $\begin{array}{c}0.295 \\
(0.370)\end{array}$ & $\begin{array}{c}0.194 \\
(0.184)\end{array}$ & $\begin{array}{l}-0.148 \\
(0.311)\end{array}$ & $\begin{array}{c}0.472 \\
(0.408)\end{array}$ \\
\hline ln(Capability Ratio) & $\begin{array}{l}-0.173 \\
(0.130)\end{array}$ & $\begin{array}{c}-0.103 \\
(0.0885)\end{array}$ & $\begin{array}{c}-0.189^{* *} \\
(0.0428)\end{array}$ & $\begin{array}{l}-0.0843 \\
(0.0650)\end{array}$ & $\begin{array}{c}0.0263 \\
(0.0809)\end{array}$ \\
\hline Previous MID, 10 yrs & $\begin{array}{c}0.472 \\
(0.358)\end{array}$ & $\begin{array}{l}-0.256 \\
(0.306)\end{array}$ & $\begin{array}{l}0.0435 \\
(0.158)\end{array}$ & $\begin{array}{l}-0.195 \\
(0.313)\end{array}$ & $\begin{array}{c}0.549 \\
(0.363)\end{array}$ \\
\hline Territorial Issue & $\begin{array}{l}-0.909 \\
(0.565)\end{array}$ & $\begin{array}{l}-0.134 \\
(0.311)\end{array}$ & $\begin{array}{r}-0.0630 \\
(0.173)\end{array}$ & $\begin{array}{l}0.0165 \\
(0.260)\end{array}$ & $\begin{array}{c}0.500 \\
(0.423)\end{array}$ \\
\hline Previous 3rd Party Attempts & $\begin{array}{c}-0.354^{* *} \\
(0.132)\end{array}$ & $\begin{array}{l}-0.0246 \\
(0.0662)\end{array}$ & $\begin{array}{l}0.00781 \\
(0.0278)\end{array}$ & $\begin{array}{c}0.0381 \\
(0.0391)\end{array}$ & $\begin{array}{l}-0.167 \\
(0.105)\end{array}$ \\
\hline $\ln$ (Claim Duration) & $\begin{array}{c}0.288 \\
(0.188)\end{array}$ & $\begin{array}{l}-0.0207 \\
(0.0780)\end{array}$ & $\begin{array}{l}0.226^{* *} \\
(0.0607)\end{array}$ & $\begin{array}{l}-0.159^{* *} \\
(0.0597)\end{array}$ & $\begin{array}{l}-0.0128 \\
(0.0767)\end{array}$ \\
\hline Other Claims & $\begin{array}{l}0.0817 \\
(0.123)\end{array}$ & $\begin{array}{l}0.0250 \\
(0.110)\end{array}$ & $\begin{array}{c}0.0821 \\
(0.0687)\end{array}$ & $\begin{array}{c}0.125 \\
(0.0884)\end{array}$ & $\begin{array}{c}-0.0680 \\
(0.111)\end{array}$ \\
\hline Pacific Settlement Commitments & $\begin{array}{c}0.0868 \\
(0.0790)\end{array}$ & $\begin{array}{l}-0.0513 \\
(0.0637)\end{array}$ & $\begin{array}{c}0.0120 \\
(0.0344)\end{array}$ & $\begin{array}{c}0.0481 \\
(0.0647)\end{array}$ & $\begin{array}{c}0.0179 \\
(0.0660)\end{array}$ \\
\hline Conflict Management Successes, 5 yrs & $\begin{array}{l}0.266^{*} \\
(0.148)\end{array}$ & $\begin{array}{c}-0.0883 \\
(0.173)\end{array}$ & $\begin{array}{l}0.0402 \\
(0.103)\end{array}$ & $\begin{array}{c}-0.0563 \\
(0.121)\end{array}$ & $\begin{array}{l}-0.134 \\
(0.162)\end{array}$ \\
\hline Constant & $\begin{array}{c}-4.066^{* *} \\
(1.219)\end{array}$ & $\begin{array}{l}-1.413^{*} \\
(0.775)\end{array}$ & $\begin{array}{c}-1.604^{* *} \\
(0.492)\end{array}$ & $\begin{array}{l}-0.355 \\
(0.604)\end{array}$ & $\begin{array}{c}-2.498^{* *} \\
(0.901)\end{array}$ \\
\hline Observations & 1601 & 1601 & 1601 & 1601 & 1601 \\
\hline
\end{tabular}

${ }^{* *} p<0.01,{ }^{*} p<0.05$ in a one-tailed test. Standard errors in parentheses. 
Table 5: Logit Model of Concessions, Interaction Models

\begin{tabular}{|c|c|c|}
\hline IV & $\begin{array}{c}\text { 1: } \\
\text { Challenger }\end{array}$ & $\begin{array}{c}2: \\
\text { Defender }\end{array}$ \\
\hline Binding Third-Party & $\begin{array}{l}2.110^{*} \\
(0.950)\end{array}$ & $\begin{array}{c}1.042^{* *} \\
(0.325)\end{array}$ \\
\hline Binding * Challenger Salience & $\begin{array}{c}0.284 \\
(0.543)\end{array}$ & \\
\hline Binding $*$ Target Salience & $\begin{array}{l}-0.159 \\
(0.509)\end{array}$ & \\
\hline Binding * Conflict Management Failures & & $\begin{array}{l}0.267^{*} \\
(0.158)\end{array}$ \\
\hline Mediation & $\begin{array}{l}-0.222 \\
(0.905)\end{array}$ & $\begin{array}{c}-0.00104 \\
(0.516)\end{array}$ \\
\hline Mediation * Challenger Salience & $\begin{array}{l}0.612^{*} \\
(0.359)\end{array}$ & \\
\hline Mediation * Target Salience & $\begin{array}{l}-0.342 \\
(0.365)\end{array}$ & \\
\hline Mediation $*$ Conflict Management Failures & & $\begin{array}{l}-0.481 \\
(0.356)\end{array}$ \\
\hline Challenger Salience & $\begin{array}{l}-0.361 \\
(0.223)\end{array}$ & \\
\hline Target Salience & $\begin{array}{c}0.266 \\
(0.208)\end{array}$ & \\
\hline Dyadic Salience & & $\begin{array}{l}0.00777 \\
(0.0427)\end{array}$ \\
\hline Conflict Management Failures, 5 yrs & $\begin{array}{l}-0.0195 \\
(0.0677)\end{array}$ & $\begin{array}{l}-0.0908 \\
(0.0703)\end{array}$ \\
\hline Competitive Gov., dyad & $\begin{array}{l}-0.135 \\
(0.297)\end{array}$ & $\begin{array}{r}-0.0207 \\
(0.255)\end{array}$ \\
\hline ln(Capability Ratio) & $\begin{array}{l}-0.0926 \\
(0.0791)\end{array}$ & $\begin{array}{c}0.0287 \\
(0.0502)\end{array}$ \\
\hline Previous MID, 10 yrs & $\begin{array}{c}-0.00754 \\
(0.251)\end{array}$ & $\begin{array}{c}-0.00208 \\
(0.245)\end{array}$ \\
\hline Territorial Issue & $\begin{array}{l}-0.437 \\
(0.296)\end{array}$ & $\begin{array}{c}0.211 \\
(0.221)\end{array}$ \\
\hline Previous 3rd Party Attempts & $\begin{array}{c}-0.101 \\
(0.0674)\end{array}$ & $\begin{array}{l}0.00950 \\
(0.0338)\end{array}$ \\
\hline $\ln$ (Claim Duration) & $\begin{array}{c}0.0272 \\
(0.0809)\end{array}$ & $\begin{array}{l}-0.195^{* *} \\
(0.0481)\end{array}$ \\
\hline Other Claims & $\begin{array}{c}0.00259 \\
(0.0826)\end{array}$ & $\begin{array}{c}0.0415 \\
(0.0753)\end{array}$ \\
\hline Pacific Settlement Commitments & $\begin{array}{c}-0.00371 \\
(0.0510)\end{array}$ & $\begin{array}{c}0.0287 \\
(0.0500)\end{array}$ \\
\hline Conflict Management Successes, 5 yrs & $\begin{array}{l}0.0374 \\
(0.113)\end{array}$ & $\begin{array}{l}-0.0995 \\
(0.104)\end{array}$ \\
\hline Constant & $\begin{array}{c}-2.019^{* *} \\
(0.758)\end{array}$ & $\begin{array}{l}-0.641 \\
(0.507)\end{array}$ \\
\hline Observations & 1601 & 1601 \\
\hline
\end{tabular}

${ }^{* *} p<0.01,{ }^{*} p<0.05$ in a one-tailed test. Standard errors in parentheses. 


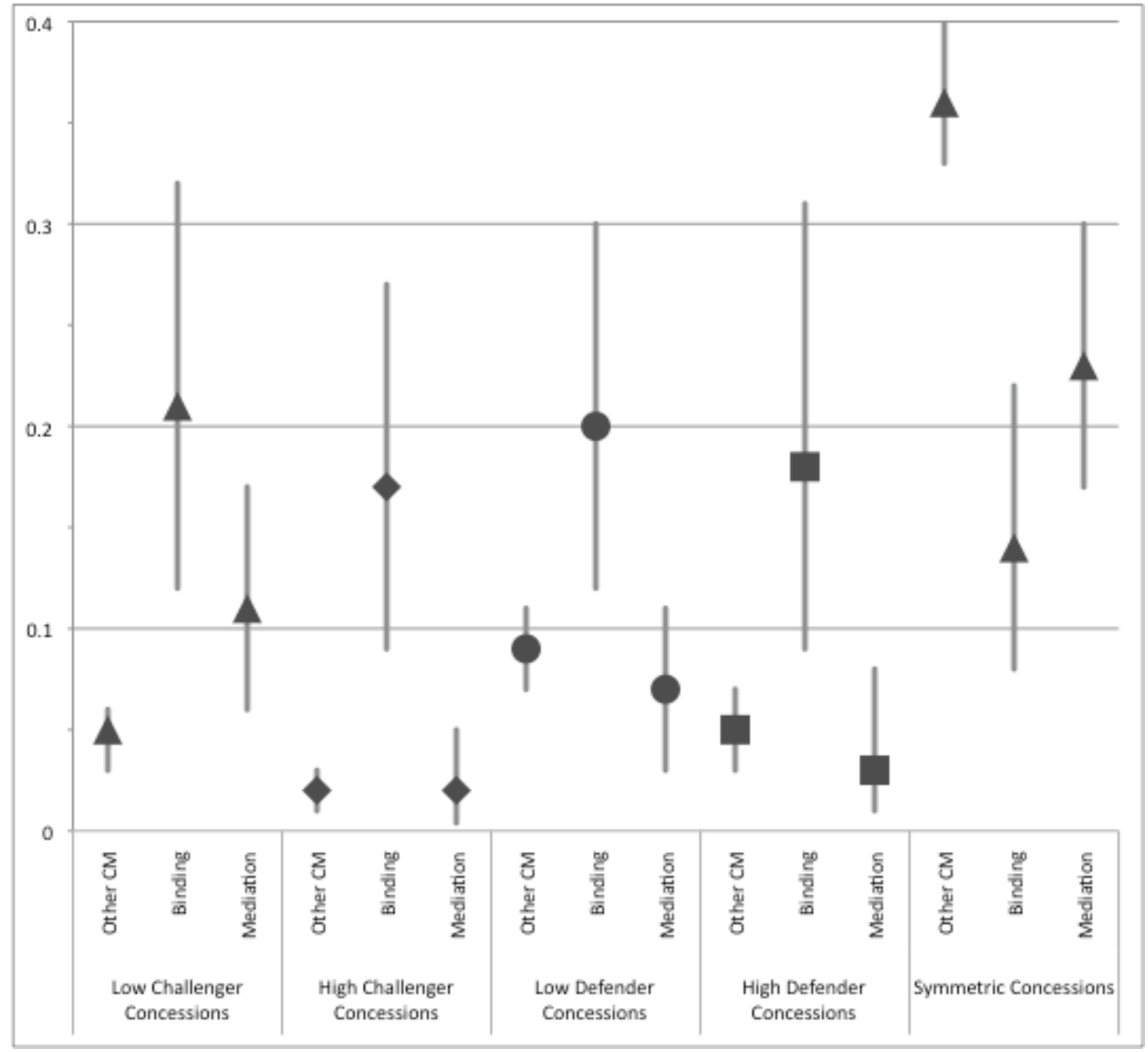

Figure 1: Predicted Probabilities of Concessions, 90\% CIs 